\title{
OTIMIZAÇÃO DO USO DE FACETAS DIRETAS COM O AUXÍLIO DE CORANTES
}

Marina Muriel TOSIN; Andrea FREIRE; Sergio VIEIRA; Mirian ZACLIKEVIS; Tamara VARGAS; Rui MAZUR

A alteração de cor de um dente tratado endodonticamente é uma consequência desagradável, prejudicando significantemente a harmonia do sorriso. A resolução estética de apenas um dente escurecido é uma situação desafiadora na dentística, onde o primeiro desafio é saber se o clareamento dental devolverá ou irá aproximar-se da cor e translucidez original do dente em questão. Quando este desafio não é vencido, ou seja, o clareamento não responde favoravelmente, a faceta direta em resina composta torna-se um recurso bastante eficaz e conservador. Assim, a seleção de cor da resina a ser utilizada bem como a associação com opacificadores e modificadores de cor são quesitos que contribuem para o resultado final da restauração. Este caso clínico ilustra a situação onde uma paciente jovem com o dente escurecido, não obteve resultado satisfatório por meio do clareamento dental. Desta forma a realização da faceta direta em resina composta com a auxiliar utilização de corantes proporcionou o resultado de acordo com as expectativas da paciente. 